\title{
Agreed Fundamental Rules Relating to Contrast and Weighting, Diligence and Advisory Opinion, and their Jurisprudence Applications
}

\author{
Dr. Mohammad Shareef Mustafa Isteti (Associate Professor) \\ The World Islamic Sciences and Education University, \\ Faculty of Figh Hanafi, Amman, Jordan
}

Doi:10.19044/esj.2019.v15n14p136 URL:http://dx.doi.org/10.19044/esj.2019.v15n14p136

\begin{abstract}
This paper focuses on addressing agreed fundamentals between fundamentalists, relating to contrast and weighting, diligence and advisory opinion with an explanation of each vocabulary base, the statement of the overall meaning, and the jurisprudence application to each rule. Basically, four rules were stated in this paper. This paper has shown that there were agreed fundamentals between fundamentalists. Hence, this serves as an alert to students of Shari school when reading fundamentalist rules, so as to be able to distinguish between what was agreed and what was disagreed. In addition, this paper contributes to the development of jurisprudential talent of students of Islamic Sharia through explaining the vocabularies of the rules, the statement of their meaning, and the jurisprudential applications on the fundamentalism rules.
\end{abstract}

Keywords: Fundamentals, Contrast and Weighting, Diligence and Advisory Opinion, Jurisprudence application

\section{Introduction}

All praise is due to Allah and peace and blessings are upon his honorable Prophets and Messengers, Muhammad bin Abdullah, his family and his companions divine, who marched on their way to the Day of Judgment.

The provisions of the rules are holistic fundamentalist reached out to devise legal provisions of the detailed evidence or Weighting between opposing doctrinal statements. Thus, knowing these rules is one of the core of understanding religion. These rules have been derived from sources; the first is Quran, the second is Sunnah, and the third is consensus. Hence, this research addresses some of the rules of agreed fundamentals, related to Sharia Ruling, to show that the fundamental rules include what is agreed and what is disagreed. 


\section{Research Importance}

This research derives its significance by drawing attention to the rules of fundamentalism, which is the core of the principles of jurisprudence. The rest of its issues and researches are a clarification of these rules, some of which is agreed and some of which is disagreed. The agreed rules were considered as axioms, while the disagreed rules were dealt with based on the knowledge of those who gave the rule and those who opposes it. This is done with the evidence of each team and by discussing it until the professors of jurisprudence and assets agreed on one.

\section{Research Problem and Questions}

This research tries to answer the following questions:

1 - Is there a correlation between consensus and the fundamental rules?

2- How can we help the students to know the agreed fundamental rules?

3- What is the fundamentalists' effort in clarifying the agreed fundamentalist rules?

4- How can we develop the jurisprudential and fundamental talent of Shari school students?

\section{Research Aims}

This research aims to achieve the following objectives:

1 - The meaning of fundamental rules.

2- The division of fundamental rules to agreed and disagreed rules. research.

3- The fundamental rules vocabulary meanings that featured in the

4- The fundamental rules total meanings that featured in the research.

5- Jurisprudential applications on the fundamental rules that featured in the research.

\section{Previous Studies}

This type of study has not been singled out - as I know - but Mustafa Bo Aqel, in his book "fundamentalists consensus: collect and study", which was originally an academic thesis introduced to the Faculty of Islamic Sciences at the University of Algiers, included an introductory chapter and five sections.

The introductory chapter addressed authoritative consensuses, its bases, divisions, areas of consensus, and fundamentalists care of it.

The first section addressed consensuses related to provisions evidences (total evidences).

The second section addressed consensuses related to semantics.

The third section addressed consensuses related to Islamic ruling and supplies. 
The fourth section addressed consensuses related to conflict, weighting, and copies.

The fifth section addressed consensuses related to diligence, imitation, and religious opinion.

The number of consensuses mentioned was 212. 125 of them were true, and approach that was taken was mentioning "consensus of ....." After then, it mentions those who agreed from the fundamentalists and those who disagreed, and it later discusses and weights them with no mention of practical examples of the issues mentioned.

Subsequently, there are many advantages of this book, including:

1. It cautioned that there are agreed fundamentalist issues and rules.

2- It is a must be sure before you say that this issue or rule is agreed.

It was shown by the researcher in the previous study that the number of consensuses that likely agreed was 125 out of 212 consensuses.

Consequently, this research has added the following matters:

1- Attention to the fundamentalism rules including what is the agreed and what is disagreed.

2- Explaining the vocabularies of four agreed fundamental rules.

3- Explaining of the total meaning of four agreed fundamental rules.

4- Attention to build branches on assets, by mentioning one jurisprudential application on each agreed fundamental rule.

\section{Research Methodology}

The research is dependent on the following approaches:

1- Inductive approach: through extrapolation and following the agreed fundamental rules.

2-Descriptive approach: through the explanation of the total meaning of four agreed fundamental rules, with an example of one jurisprudential application on each rule.

\section{Research Plan}

The research included an introductory, two sections, and a conclusion.

The introductory addressed research importance and aims, previous studies, and research methodology.

The primary section addressed the fundamental rules related to contrast and weighting. Thus, it comprises of two demands:

Demand (1): Addressed the rule: It is permissible to contradict between the two suspicion evidences in the consideration of the diligent person. Also, it includes four branches:

Branch (1): Who agreed on the consensus of the rule?

Branch (2): Explaining the vocabularies of the rule.

Branch (3): The total meaning of the rule. 
Branch (4): An application of the rule.

Demand (2): Addressed the rule: It is necessary to work with the weighted evidences. Thus, it includes four branches:

Branch (1): Who agreed on the consensus of the rule?

Branch (2): Explaining the vocabularies of the rule.

Branch (3): The total meaning of the rule.

Branch (4): An application of the rule.

The second section addressed the fundamental rules related to diligence and advisory opinion, and it included two demands:

Demand (1): Addressed the rule: Sin is falling from the wronged in diligence. Thus, it includes four branches:

Branch (1): Who agreed on the consensus of the rule?

Branch (2): Explaining the vocabularies of the rule.

Branch (3): The total meaning of the rule.

Branch (4): An application of the rule.

Demand (2): Addressed the rule: The necessary matters for those who give a religious verdict to the people are: Islam, assignment, and justice. Thus, it includes four branches:

Branch (1): Who agreed on the consensus of the rule?

Branch (2): Explaining the vocabularies of the rule.

Branch (3): The total meaning of the rule.

Branch (4): An application of the rule.

The conclusion addressed the most important results of the research.

\section{The Primary Section}

\section{Fundamental Rules related to Contrast and Weighting}

It included two demands:

Demand (1)

The first rule: It is permissible to contradict between the two suspicion evidences in the consideration of the diligent person

It includes four branches:

\section{Branch (1): Who agreed on the consensus of the rule?}

A number of fundamentalists recounted consensus on this rule, including Al-Razi, who said: "There is no dispute about the occurrence of a tie - the contradiction - according to our minds (Al-Razi, 1992, 5/384)". Al-Isnawi said: "The two portents: that is, the two suspicion evidences may be contradicted in the diligent person by agreement (Al-Isnawi, 1981, p.505)". Al-Badkhashi said: "The contradiction of two portents means their equality and the diligent person is permissible in agreement (Al-Badkhashi, 1516, 3/150)". 


\section{Branch (2): Explaining the vocabularies of the rule.}

It is permissible: accepted (Omar, 2008, 1/419) justified (Redha, 1958, 1/600), and the permissible. It includes the permissible, the delegate, the disapproved, and the duty (Qalaa-Jee \& Qunaibi, 1988, p.157).

Contradiction: It means the opposition, and it is said: To contradicts a thing with another thing, means to do opposites it, and I contradicted my book with his book, means: I opposed it (Ibn Mandhour, 2000, 10/100). The opposition to the fundamentalists is the correspondence of two evidences, even they are general - in the most correct way of opposition (Ibn Al-Najjar, 1993, 4/605).

Between: Adverb of place.

Evidence: in language: The guide and the detector (Al-Fayyoumi, N.D., 1/199), and it conventionally means: what can be properly considered as a propositional demand (Al-Eeji, 2016, 1/112).

Suspicion: in language: This indicates two different meanings: a certainty and an imminent, as for the certainty in the saying: I thought an assumption, means I am certain, meanwhile, we say: I thought the thing, if I am not certain it (Ibn Zakaria, 2001, p.615). It means that conventionally, the most likely belief is based on the possibility of contrast (Al-Jerjani, 1992, p.187).

In: A preposition means inside.

Consider: Thinking and Study (Omar, 2008, 3/2233).

Diligent person: A scientist who managed the instruments of diligence in an age of times (Sano, 2000, p.386).

\section{Branch (3): The total meaning of the rule}

It is acceptable to meet two guides that are similar. Thus, everyone has two or more sides, so that each of them prevents the other, as if one of them indicates that some act is forbidden and the other evidence indicates that it is permissible. This prevention between the two evidences does not actually mean the same matter, but it is only in the mind, thinking, and opinion of the diligent person.

\section{Branch (4): An application of the rule}

The apparent contradiction between the words of the Prophet (peace and blessings of Allah be upon him): "(The tenth) for what the sky and the spring, or if the land is wet due to a nearby water channel (Ibn Al-Atheer, N.D., P.578) were irrigated (Al-Bukhari, 2012, 1/484)". And the Prophet (peace and blessings of Allah be upon him) said: "For less than five awsuq (Qalaa-Jee \& Qunaibi, 1988, p.450) there is no charity (Al-Bukhari, 2012, 1/484)".

The first hadeeth is absolute. Hence, it reported that the zakat is due regardless of the amount of agricultural wealth that zakat is due on. Whereas 
the second hadeeth indicates that it must not be obtained with an amount of less than five awsuq.

This conflict is ostensibly opposed only. It can be removed by combining the two hadeeths such that the first hadeeth should be up to five awsuq. This means that what the sky watered the tenth if it reached five awsuq or more of what zakat is a duty for it.

Ibn Qudamah said that zakat is not obligatory on anything from crops and fruits until it reach five awsuq. This is the view of the most knowledgeable scholars, among them: Ibn Umar, Jaber, Abu Amamah Ibn Sahl, Omar Bin Abdul Aziz, Jaber Bin Zaid, Al-Hassan, Ata, Makhkul, Al-Hakam, Al-Nakhai, Malik, the people of Madina, Al-Thawri, Al-Aozai, Ibn Abi Laila, Shafi'i, Abu Yusuf, Muhammad, and other scholars. However, we do not know anyone who disagreed with them except Mujahid and Abu Haneefa and those who followed him. They said: It is obligatory to pay zakat on a small amount of that and many of it, according to the hadeeth of the Prophet (peace and blessings of Allah be upon him): "The tenth of what sky watered". And because it has no periodic time, there is no zakat for it. For us, the Prophet (peace and blessings of Allah be upon him) said: "There is no charity for what is less than five awsuq" as agreed upon. This is a special thing that must be presented and allocated to the general public (Ibn Qudamah, 1997, 4/161).

Demand (2)

The second rule: It is necessary to work with the weighted evidences It includes four branches:

\section{Branch (1): Who agreed on the consensus of the rule?}

A number of fundamentalists recounted consensus on this rule, including Al-Juwaini. He said: "The second part of the news is the one that does not require knowledge. If two of them are opposed, then it is possible to combine them with a mixture of interpretation, or if there is no combination between them, it is possible to weight one of them on the other, if it is most likely to believe its truth and steadfastness, even if this does not lead us to knowledge. The evidence for this is consensus at first, the people who say the news is the one agreed on the weighting of each other and adhere to what strengthens by weighting (Al-Juwaini, 2007, 2/435-436)". Al-Razi, said: "consensus of the companions to work is weighted (Al-Razi, 1992, 5/398)". Al-Zarkashi said, "If the weighting is achieved, then it is necessary to act fairly and neglect the other, for the consensus of the companions to work according to what is likely weighted to them in the news (Al-Zarkashi, 1994, 8/145)". Ibn Zakari said: "If the clear evidences are weighted on the hidden, it is obligatory to foreword the clear on the hidden, and it is obligatory to work with the weighted by the 
companions (may Allah be pleased with them) to foreword the most correct and to do with it (Ibn Zakari, 2005, 2/752)".

\section{Branch (2): Explaining the vocabularies of the rule}

Necessary to work: Obligatory (Ibn Mandhour, 2000, 15/154) to work.

With: A proposition includes imputation to something.

Weighted: The weighting is to prove the credit on one side of two opposite sides, or to make the thing preferable (Al-Shawkani, 2000, 2/1113). In the terminology of the fundamentalists, it means a statement of diligence to force one of the evidences on the other to work with the strongest and to reject the other (Obeidat, 2012, p.109).

Evidences: The singular is evidence, which is the guide and the detector (Al-Fayyoumi, N.D., 1/199). Hence, it conventionally means: what can be properly considered as a propositional demand (Al-Eeji, 2016, 1/112).

\section{Branch (3): The total meaning of the rule}

In the event of a conflict between two evidences, if the diligent pushed this contradiction by strengthening each other, the diligent and imitates are obligated to work with the strongest evidence.

Branch (4): An application of the rule: The contradiction between what was stated in the legality of the marriage without specifying the number, with the determination of what is legal by four wives.

In Surat al-Nisa ' after Allah mentioned women unmarriageable to

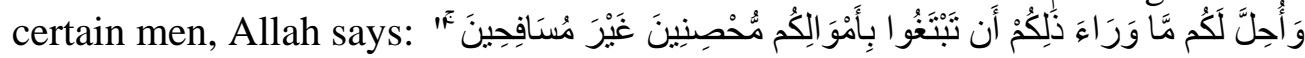
" (Surat al-Nisa ', Verse: 24), and Allah says in other verse:

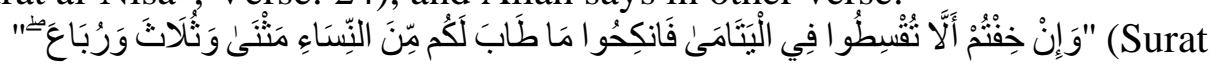
al-Nisa ', Verse: 3 ).

The first verse indicates the legality of marriage of a non-mahram that is mentioned previously without specifying a number. This signifies apparently that it is permissible for a man, according to this general rule, to gather more than four wives in his bond of marriage. And the second verse: is a (text) in the exclusive of legality to four women. Thus, the increase of this number is forbidden.

Thus, the contradiction, beyond the four, which is legal in the first verse is illegal in the second verse, and in this case the stronger is presented: the text is more correct, namely, fixing the number to four at most, and forbidding what is behind it, which does not restrict the number of wives that the man can marry legally. So the second evidence is stronger than the first because the text is valid for the benefit of this provision: that is, determination of what is permissible for a Muslim man by four women. Hence, it was prescribed by Shari'a that it is illicit for Muslim man to gather more than four wives in his 
bond of marriage (Saleh, 1984, 1/179-180). So the benefit of the provision is that we cannot work with the first text but we can work with the second text.

\section{The second section}

Fundamental Rules related to Diligence and Advisory Opinion

It included two demands:

Demand (1)

The first rule: Sin is falling from the wronged in diligence It includes four branches:

\section{Branch (1): Who agreed on the consensus of the rule?}

A number of fundamentalists recounted consensus on this rule, including Al-Amidi. He said: "The people of truth have agreed that the sin is falling from those who are diligent in the rulings of the shar'ia. Bishr Al-Muraisi, Ibn Olaya, Abu Bakr Al-Asam, and those who deny measurement, such as: the Apparent and Imami, agreed that every problem has a right in it, and has a conclusive evidence, and who made a mistake is a sinner not a disbeliever nor wicked (Al-Amidi, 1981, 3/218)". Al-Rahwani said: "In the provisions of subdiligence, we cut the sin of the diligent if wronged. Bishr Al-Muraisi was quoted from the Mu'tazilah, and from Abu Bakr Al-Asam: The wronged is a sinner, and it is not valid for them to disagree, because after the consensus for us: The conclusive as a frequency is that the Companions have differed in matters of diligent, it was repeated, common and undeniable, and no sin by each other, that one of the violators say that the other is a sinner, and it is not vague that one of them says the other is sinner, with the firm that if he was sinful, then the habit will mention him, and they will be afraid of diligence and avoid it, and frighten others of it, so since they did not speak in the sin of that, it is known absolutely not to be a sin (Al-Rahwani, 2002, 4/256-257)". I believe that this nullifies sinning of a diligent error.

\section{Branch (2): Explaining the vocabularies of the rule.}

Sin: Guilt (Ibn Mandhour, 2000, 1/56), and rightfully: the guilt that deserves punishment, and it is not correct to be described only by the mahram (Al-Kafawi, 1993, p.40).

Falling: Putting down, we say: falling the thing, means putting it down (Omar, 2008, 3/2456).

From: A proposition includes exceeding.

Wronged: The error which is when a person has no intention (Al-Jerjani, 1992, p.134).

In: A proposition means reasoning. 
Diligence: The jurist extraction of the easiest to obtain a legal opinion (Al-Eeji, 2016, 2/917).

\section{Branch (3): The total meaning of the rule}

If the person who fulfills the conditions of diligence has the ability to reach a shar'ia ruling from the evidences, then what he reaches is either right or wrong. If the diligent is right, he has two rewards: diligence reward and the right reward, even if he is in error, he has the reward of diligence, and there is no sin on him, because the Prophet (peace and blessings of Allah be upon him) said: "If the judge rules by diligence, and the judgment is correct, he will have two rewards. If he is judged by diligence, and the judgment is wrong, he will have one reward (Al-Bukhari, 2012, 2/736)". The interpretation of this Hadith nullifies sinning of a diligent error.

Branch (4): An application of the rule: Slaughtering of slaughtered animal fetus.

It is proven in the hadeeth that the Messenger of Allah (peace and blessings of Allah be upon him) said: "The slaughter of the fetus is the slaughter of its mother (Ibn Biliban, 1997, 13/207; Al-Darimi, 2002, p.267; Al-Hakem, 2002, 4/127; Ibn Majeh, 2009, p.560; Al-Tirmidhi, 2011, p.640)". The meaning of the hadeeth is that if the fetus comes out dead from his mother after slaughtering it, it is lawful. Abu Haneefah (may Allah have mercy on him) disagreed, and he said: "It is not eaten (Al-Kasani, 2003, 6/212)". This has been contrary to the hadeeth that came from the Messenger of Allah, peace be upon him, and he is excused of being rewarded with no sin on him. Thus, this is because he did not intend to violate the hadeeth, but did not prove it, and it is contrary to the fundamentals. Ibn Rushd said: The reason for their difference is that they differed as to the validity of the narrated effect in that of the hadeeth of Abu Sa'eed al-Khudri, while he contradicted the fundamentals. The hadeeth of Abu Sa'eed stated: "We asked the Messenger of Allah (peace and blessings of Allah be upon him) about the cow or the camel or sheep, we slaughter it and we find a fetus in its abdomen, shall we eat it or throw it? he said: eat it if you like, its slaughter is the slaughter of its mother. This was documented by Al-Tirmidhi and Abu Dawood from Jaber, and they differed in the correction of this effect, some did not correct it except for AlTirmidhi. The fundamental disagreement in this section is that if the fetus was alive and then died by the death of its mother, it dies by suffocating; so it was killed by strangling, which is forbidden by text (Ibn Rushd, 1978, 1/442-443)".

Demand (2)

The second rule: The necessary matters for those who give a religious verdict to the people are: Islam, assignment and justice 
It includes four branches:

\section{Branch (1): Who agreed on the consensus of the rule?}

A number of fundamentalists' recounted consensus on this rule. Among them is Ibn Hamdan who said: "It is his attribute and conditions to be a fair Muslim, assigned, diligent, vigilant, true minded, and thought and act in the jurisprudence and what is related to it. As for the requirement of Islam, assignment and justice, it is unanimously, because it tells about God in his judgment; so Islam, assignment and justice were required to gain confidence of his saying, and depend on him in things, such as witness and narration (Ibn Hamdan, 1397HJ, p.13)".

\section{Branch (2): Explaining the vocabularies of the rule}

Necessary: Obligatory (Ibn Mandhour, 2000, 8/56).

For those: A proposition followed by linked name.

Give a religious verdict: Show the shar'ia ruling for the asker (AlBahwati, 2000, 6/457).

People: The name of Adam's sons collection (the one is a person) (Omar, 2008, 3/2305).

Islam: To be a Muslim.

Assignment: To be assigned, who is the wise minded Muslim, that the conditions of the assignment are provided, such as: mind, maturity, and safety of legal impediment. In addition, he is named the condemned (Sano, 2000, p.440).

Justice: To be fair, justice is an aptitude that carries its owner to piety, and to avoid the impurity and what is harmful to the people (Al-Ghauri, 2012, p.485).

\section{Branch (3): The total meaning of the rule}

The mufti is a deputy of the Prophet (peace and blessings of Allah be upon him) in the statement of the shar'ia rulings. Therefore, it is necessary for someone who wants to deal with the fatwa to have important conditions, such as:

1 - Islam, because the Mufti tells about the rule of God. He informs us about the law of God, and apply the provisions on the facts and events. So he must be a believer of God and his Messenger Muhammad (peace be upon him), and the law of God which was given by his messenger peace be upon him (Zeidan, 1976, p.141).

2 - Assignment, the Mufti must have a rational mind of the provisions of Sharia. He must understand and know it, and the lowest considered degree of the mind is the maturity. Hence, the requirement of the assignment is that the Muslim must be a mature minded person (Zeidan, 1976, p.142). 
3 - Justice, the Mufti must be reliable, safe, infallible of the causes of immorality, and the slights of virility, because if it is not so, his saying will not suitable for adoption, despite the fact that he was from the diligent people (Ibn Al-Salah, 1986, p.86).

\section{Branch (4): An application of the rule: Ruling on putting the immoral person to give the fatwa}

Immorality is neglecting God's command, exiting from the truth way, and debauchery (Al-Kafawi, 1993, p.692-693). Thus, the fatwa of the immoral is not valid.

Al-Khatib Al-Baghdadi said when he spoke about the conditions of those who fit the fatwa: "Then he is justly confident, because the Muslim scholars did not disagree that the immoral is not acceptable to the fatwa in the rulings of religion, even if he is aware of it (Al-Baghdadi, 1426HJ, 2/330)".

Ibn Hamdan said: "Fatwa is not valid from an immoral person to someone else, even if he is diligent, he can make fatwa for himself, but the other don't ask him (Ibn Hamdan, 1397HJ, p.29). Al-Nawawi said: "The condition of the mufti is that he must be an assigned Muslim, reliable, safe, infallible of the causes of immorality, self expert, sound mind, composed thought, correct behavior and deductive, and awake (Al-Nawawi, N.D., 1/74).

\section{Conclusion}

\section{The Most Important Results through Research}

Praise be to God that His grace is righteousness, peace and blessings be upon the master of the first people and others, Mohammed bin Abdullah, who walked on his approach to the Day of Judgment. I can summarize the most important results in this research as follows:

First: The fundamental rules are holistic provisions that was reached to derive legitimacy provisions, or weighting between the conflicting jurisprudence.

Second: The third source of fundamentalism derive rules is consensus.

Third: Fundamentalists have commendable efforts in clarifying the agreed fundamental rules.

Fourth: There are many agreed fundamental rules, and I have extrapolated fundamental books and extracted four rules related to Contrast and Weighting, Diligence and Advisory Opinion. Also, I explained its vocabulary, clarified its general meaning, and mentioned one application on each rule.

Fifth: The Fundamentalist talent can be developed among Sharia students through the application of branches to assets. Also, the Sharia student must distinguish between agreed fundamental rules and disagreed 
fundamental rules. The agreed rules are constant, meanwhile the disagreed rules have diligence.

Sixth: The rules in question work for contemporary times; political economy, governance and justice and other fields of research can be built on these rules, for example: the restriction of fasting hours in some countries, such as Finland. Thus, this was left for diligent men to solve this problem, and every diligent has at least one reward.

I ask Allah to accept this work and make it in the balance of my good deeds on the Day of Judgment. Allah is the conciliator and the guide to the right path. And Praise be to Allah, the Lord of the Worlds.

\section{References:}

1. Al-Amidi Ali bin Mohammad (1981). The Accuracy in Fundamentals of Provisions, Dar Al-Fikr, Beirut, without mentioning the publication place, first edition, $1401 \mathrm{HJ}-1981$ AD.

2. Al-Badkhashi Mohammad bin Al-Hasan (1516). Explanation of AlBadakhshi (curriculum of minds), Mohammad Ali Sobh and Sons Press in Al-Azhar, Egypt, without mentioning the publication place and date, $922 \mathrm{HJ}-1516 \mathrm{AD}$.

3. Al-Baghdadi Ahmad bin Ali bin Thabet Al-Khatib (1426). Book of Faqih and Mutafaqeh, verified by: Adel bin Yousef Al-Azazi, Dar Ibn Al-Jawzi, Al-Dammam, third edition, 1426 HJ.

4. Al-Bahwati Mansour bin Younes (2000). The Ultimate of Wills Explanation, verified by: Abdullah bin Abdul-Mohsen Al-Turki, AlResala Establishment Publishers, Damascus, first edition, $1421 \mathrm{HJ}-$ 2000 AD.

5. Al-Bukhari Mohammad bin Ismail (2012). Sahih Bukhari, Hadiths documented and commented on by Izzeddin Dhelly, Imad Al-Tayyar, and Yaser Hasan, AL-Resala Establishment Publishers, Damascus, new print, $1433 \mathrm{HJ}$ - 2012 AD.

6. Al-Darimi Abdullah bin Abdul-Rahman bin Al-Fadhel bin Behram (2002). Al-Darimi Musnad, known as Al-Darimi Sunan, Dar Ibn Hazm, Beirut, first edition, 1423 HJ - 2002 AD.

7. Al-Eeji Abdul-Rahman bin Ahmad (2016). Explanation of the Reinforce on a Brief of Ultimate Access and hope for the Assets and Controversy Sciences, a study and investigation of: Ali bin Abdul-Rahman Bassam Al-Jazaeri, Dar Ibadul-Rahman, Cairo, and Ibn Hazm Dar, Beirut, first print, 1437 HJ - 2016 AD.

8. Al-Fayyoumi Ahmad. The Enlightening Lamp, the Scientific Library, Beirut, no print and no publication date. 
9. Al-Ghauri Sayyed Abdul-Majid (2012). Hadeeth's Terms Dictionary, Dar Ibn Katheer, Damascus, second edition, 1433 HJ 2012 AD.

10. Al-Hakem Mohammad bin Abdullah Al-Naisabori (2002). AlMustadrak on two Sahihs, study and investigation of: Mustafa Abdul-Qader Ata, the Scientific Books Dar, Beirut, second edition, 1422 HJ - 2002 AD.

11. Al-Isnawi Abdul-Rahim bin Al-Hasan (1981). A preface of Graduation of Branches on Assets, verified, commented upon and documented by Mohammad Hasan Heto, Al-Resala Establishment, Beirut, second edition, $1401 \mathrm{HJ}$ - 1981 AD.

12. Al-Jerjani Ali bin Mohammad bin Ali (1992). Book of Definitions, verified, introduced to and indexed by: Ibrahim Al-Abiari, the Arabic Book Dar, Beirut, second edition, 1413 HJ - 1992 AD.

13. Al-Juwaini Abdul-Malik bin Abdullah bin Yousef (2007). The Summary in the Fundamentals of Jurisprudence, Investigation of Abdullah Gulm AL-Nepali, and Shubair Ahmed Al-Omari, AlBashaer Islamic Dar, Beirut, second edition, 1428 HJ - 2007 AD.

14. Al-Kafawi Ayyoub bin Mousa Al-Husaini (1993). The Majors, confronted in a linear copy, prepared for printing, and indexed by: Adnan Darwish and Mohammad Al-Masri, Al-Resala Establishment, Beirut, second edition, 1413 HJ - 1993 AD.

15. Al-Kasani Abu Baker bin Masoud bin Ahmad (2003). The Brilliant Made in the Arrangement of Canons, the Scientific Books Dar, Beirut, second edition, $1424 \mathrm{HJ}$ - 2003 AD.

16. Al-Nawawi Yahya bin Sharaf. Book of Total: Polite Explanation, verified, commented upon and completed after its diminution by Mohammad Najib Al-Mutai'i, Library of Guidance, Jeddah, without mentioning the edition, and the date of publication.

17. Al-Rahwani Yahya bin Mousa (2002). Masterpiece Charge in a Brief of the Soul Ultimate Explanation, study and investigation of: Yousef Al-Akhdar Al-Qayyim, Dar of Research for Islamic Studies and Heritage Revival, Dubai, first edition, 1422 HJ - 2002 AD.

18. Al-Razi Mohammad bin Omar bin Al-Husain (1992). The Incomings of Jurisprudence, study and investigation of: Taha Jaber Al-Alwani, Al-Resala Establishment, Beirut, second edition, 1412HJ - 1992 AD.

19. Al-Shawkani Mohammad bin Ali (2000). Stallions' Guidance to Achieve the Right of the Assets Science, investigation and comment of: Sami bin Al-Arabi Al-Athari, Virtue Dar, Riyadh, first print, 1421 HJ - 2000 AD.

20. Al-Tirmidhi Mohammad bin Isa bin Surah (2011). Sunan AlTirmidhi, Hadiths were documented and commented on by Izzeddin 
Dhelly, Emad al-Tayyar, and Yasser Hassan, Al-Resala Establishment Publishers, Damascus, first edition, 1432 HJ - 2011 AD.

21. Al-Zarkashi Mohammad bin Bahader (1994). The Surrounding Moon, Hadiths were verified and documented by a Committee of Scholars of Al-Azhar, Dar al-Kutbi, Cairo, first edition, 1414 HJ 1994 AD.

22. Ibn Al-Atheer Al-Mubarak bin Mohammad. The End in the Strange of Speech and Effect, cared by: Raed bin Sabri bin Abi Alfa, the international thoughts House, without mentioning the edition and date of publication.

23. Ibn Al-Najjar Mohammad bin Ahmad bin Abdul-Aziz (1993). Explanation of the Bright Planet, verified by Mohammad al-Zuhaili, Nazih Hammad, Obeikan Library, Riyadh, without mentioning the edition, 1413 AH - 1993 AD.

24. Ibn Al-Salah Othman bin Abdul-Rahman (1986). Literature of Mufti and Mustafti, study and investigation of Mowafaq bin Abdullah bin Abdul-Qader, Library of Science and Wisdoms, and Books Science, without mentioning the publication place, first edition, $1407 \mathrm{HJ}-1986$ AD.

25. Ibn Biliban (1997). Sahih Ibn Hibban by the Arrangement of Ibn Biliban, verified, documented and commented upon by Shoaib AlArnaout, Al-Resala Establishment, Beirut, third edition, 1418 HJ 1997 AD.

26. Ibn Hamdan Ahmad. The status of Fatwa, Mufti and Mustafti, Hadiths were documented and commented on by: Mohammad Nasereddin Al-Albani, the Islamic Office, Beirut, third edition, $1397 \mathrm{HJ}$.

27. Ibn Majeh Mohammad bin Yazeed (2009). Sunan Ibn Majeh, Hadiths were documented and commented on by Yasser Hassan, Izzeddin Dhelly, and Emad Al-Tayyar, Al-Resala Establishment Publishers, Damascus, first edition, $1430 \mathrm{HJ}-2009$ AD.

28. Ibn Mandhour (2000). Arab tongue, Dar Sader, Beirut, first edition, 2000 AD.

29. Ibn Qudamah Abdullah bin Ahmad (1997). The Enriched, investigation of Abdullah bin Abdul-Mohsen Al-Turki, Abdul-Fattah Mohammad al-Hilu, World Books Dar, Riyadh, third edition, 1417 HJ - 1997 AD.

30. Ibn Rushd (the grandson) Mohammad bin Ahmad bin Mohammad bin Ahmad (1978). The beginning of the Diligent and the end of the Intender, the Knowledge Dar, Beirut, fourth edition, 1398 HJ - 1978 AD.

31. Ibn Zakari Ahmad (2005). The Purpose of Al-Maram to Explain the Imam's Introduction, study and investigation of Mohannad Ao Edir 
Meshnan, Heritage Dar publishers, Algeria, and Ibn Hazm Dar, Beirut, first edition, $1426 \mathrm{HJ}$ - $2005 \mathrm{AD}$.

32. Ibn Zakaria Ahmad bin Fares (2001). Dictionary of Language Standards, noticed by Mohammad Awad and Fatima Mohammad Aslan, Arab Heritage Revival Dar, Beirut, first edition, 1422 HJ - 2001 AD.

33. Obeidat Khaled Mohammad (2012). Fundamentalist Approaches in Weighting between the Legal Texts, Orientals Dar, Amman, first edition, $1433 \mathrm{HJ}$ - $2012 \mathrm{AD}$.

34. Omar Ahmad Mukhtar (2008). Contemporary Arabic Dictionary, World of Books, Cairo, first edition, 1429 HJ - 2008 AD.

35. Qalaa-Jee Mohammad Rawwas \& Qunaibi Hamed (1988). Jurists language dictionary, Dar Al-Nafais, Beirut, second edition, $1408 \mathrm{HJ}$ - 1988 AD.

36. Redha Ahmad (1958). Language Board Dictionary, Library of Life, Beirut, without mentioning the edition, 1377 HJ - 1958 AD.

37. Saleh Mohammad Adeeb (1984). Interpretation of texts in Islamic jurisprudence, the Islamic Office, Beirut, third edition, $1404 \mathrm{HJ}$ 1984 AD.

38. Sano Qutb Mustafa (2000). Jurisprudence Terms Dictionary, Dar of Contemporary Fikr, Beirut, Dar Al-Fikr, Damascus, first edition, 1420 HJ - 2000 AD.

39. Zeidan Abdul-Karim (1976). Origins of Invitation, Al-Manar Islamic Library, without mentioning the publication place, third edition, 1396 HJ - 1976 AD. 